\title{
Correlación entre calidad del tendón del supraespinoso con el dolor y movilidad postquirúrgica
}

\section{Correlation between quality of the supraspinoso tendon with pain and post-surgical mobility}

\author{
Daniel E. Herrera Burgos ${ }^{1}$, Mauricio Balla ${ }^{1}$, Cristian A. Ferreyra ${ }^{1}$, Andrés M. Jalil ${ }^{1}$. \\ 1 Universidad Católica de Córdoba. Facultad de Ciencias de la Salud. Clínica Universitaria Reina Fabiola. Servicio de Ortopedia y Traumatología. \\ correspondencia: Daniel E. Herrera Burgos. Servicio de Ortopedia y Traumatología. Clínica Universitaria Reina Fabiola Oncativo 1248 -X5004FHP- Córdoba, \\ Argentina; e-mail: burgos.herrera@yahoo.com
}

\section{Introducción}

La Omalgia tiene muchas etiologías, entre las que se encuentran lesiones del manguito rotador, como causa sola o acompañada de otras comorbilidades. La ruptura del musculo supraespinoso es una de las principales causas de esta, y su lesión resulta no sola en dolor, sino también en limitación funcional.

La historia natural de las roturas del manguito rotador no siempre es predecible, por un lado, muchos son asintomáticos y responden bien al manejo conservador. Por otro lado, existen estudios que sugieren que algunos desgarros que eran previamente asintomáticos se vuelven sintomáticos y es la manifestación de dolor uno de los criterios más utilizado para el manejo quirúrgico ${ }^{1}$.

La patología del manguito rotador es muy frecuente, estudios anatómicos en cadáveres encontraron ruptura hasta el $50 \%$ de los casos, sugiriendo que puede ser parte del proceso de envejecimiento, aumentando de forma constante después de la quinta década de la vida. Otros estudios mostraron función normal aun con ruptura de espesor completo ${ }^{1,2}$.

El tratamiento quirúrgico por vía artroscópica ha tomado auge en los últimos años, ofreciendo grandes expectativas al paciente sobre el resultado postquirúrgico. Sin embargo, hay factores que pueden afectar el resultado de la cirugía como la calidad del tendón, el tamaño de la retracción y la infiltración grasa ${ }^{3}$.

La evaluación de las anormalidades del musculo del manguito rotador después de su ruptura es un factor importante para la toma de decisiones a la hora del tratamiento. La gravedad de la degeneración grasa prequirúrgica es especialmente relevante pues influye en el pronóstico y la recuperación funcional posquirúrgica. Una determinación precisa de la degeneración grasa en el musculo supraespinoso es, por lo tanto, un elemento crucial para evaluar las indicaciones quirúrgicas y el pronóstico postoperatorio ${ }^{4}$.

Se demostró que cuanto más tiempo lleven los síntomas, mayor será la degeneración grasa del musculo cuyo tendón este roto, así mismo demostró que la tasa de re-ruptura era menos cuando había mínima degeneración grasa, y que después de la reparación esta degeneración grasa del supraespinoso revertía en un $21 \%$; por otro lado, algunos estudios manifiestan que el musculo no se regenera, apoyando la idea de una pronta cirugía antes de que ocurra la degeneración grasa ${ }^{5}$. La clasificación de Goutallier es altamente aceptada como sistema estándar de calificación en 5 grados para la degeneración grasa muscular, esta se basa en imágenes de RMN sagital ${ }^{5}$. 
La pérdida de la fuerza contráctil del supraespinoso y consiguiente debilidad, está asociada a la atrofia muscular, y exacerbada por la infiltración grasa, ambos cambios degenerativos secundarios a la ruptura del manguito rotador. La medición de la infiltración grasa y la atrofia muscular preoperatoria nos ayudara a predecir la función contráctil del musculo y su recuperación ${ }^{6}$.

\section{Objetivo}

Determinar el grado de dolor y la funcionalidad postquirúrgica del tendón del supraespinoso según la calidad tendinosa prequirúrgica.

\section{Material y Método}

Estudio retrospectivo observacional descriptivo Se realizó una búsqueda en el sistema informático de historias clínicas en soporte electrónico de la clínica (HIS INNOVA ${ }^{\circledR}$ ), de todos los pacientes con desgarro total del musculo supraespinoso a los que se le realizo cirugía por vía artroscópica y vía Mini - Open, desde enero del 2016 hasta enero del 2018.

Se incluyeron paciente de todas las edades, con causa de ruptura de tipo traumática y a traumática, distinto tiempo en evolución de la enfermedad, de ambos sexo y diferente actividad laboral.

Se excluyeron pacientes con lesión de 2 o más tendones del manguito rotador, cirugías previas del hombro evaluado y a quienes el seguimiento fue inferior a 4 meses por distintas causas.

Se valoró en el prequirúrgica por medio de RMN la degeneración grasa utilizando la Clasificación de Goutallier de 0 a 4, utilizando imágenes en T1 en corte axial. El grado 0 se definió como ausencia de infiltración grasa, grado 1 como estrías grasas del supraespinoso, grado 2 como menos grasa que musculo, grado 3 como cantidades iguales de grasa y musculo, y grado 4 como más grasa que musculo ${ }^{5}$. También se valoró la atrofia muscular del supraespinoso con corte sagital a nivel del borde medial de espina escapular justo arriba de la escotadura espinoglenoidea, clasificando de 1 a 3 según el porcentaje de ocupación muscular en fosa supraespinosa así: grado 1 normal o ligera atrofia $(1-0.6)$, grado 2 moderada atrofia $(0.6-0.4)$ y grado 3 severa atrofia $(<0.4)$. Y retracción tendinosa del supraespinoso según referencias anatómicas en inserción, cabeza humeral o al nivel de la glenoides en corte coronal.

La técnica quirúrgica se realiza por vía artroscópica y abordaje Mini - Open antero lateral, se coloca 2 suturas lineal y arpones con doble sutura para aproximación del tendón a zona de Footprint, cierre de herida por planos y colocación de cabestrillo tipo Vietnam.
El control postoperatorio se realizó a los 7, 15, 30, 60 y 90 días, valorando el dolor postquirúrgico, rango de flexión y abducción tanto activo como pasivo.

Todos los pacientes iniciaron a los 7 días movimientos pendulares y flexión pasiva del hombro, a los 15 días se indicó fisioterapia para movilidad pasiva, a los 30 días movilidad activa y asistida, entre los 45 a 60 días natación (estilo Crawl o Aquagym) y/o Pilates según evolución del dolor y rango de movilidad.

El dolor, como motivo de consulta principal, se evalúo por medio de la escala EVA, con un valor numérico de 0 a 10 donde 0 es ausencia de dolor y 10 es el peor dolor inimaginable.

El rango de movimiento se evaluó en grados, tanto activos como pasivos, siempre por el mismo examinador, al igual que el grado de dolor.

\section{Resultados}

Se analizaron 16 pacientes, 7 hombres (44\%) y 9 mujeres (56\%), con rango de edad entre 45 y 70 años (media 58.6 años), valorados por medio de RMN en donde calculamos degeneración grasa con la clasificación de Goutallier de 0 a 4, obteniendo un promedio de 1.2, es decir un valor de mínima infiltración grasa. Agrupando en grado de infiltración grasa por edad en años, obtuvimos para grado 0 (media 51), grado 1 (media 59.4), grado 2 (media 60.3) y grado 3 (media de 62); no tuvimos pacientes con grado 4. Comparados con tiempo de evolución desde diagnostico hasta manejo quirúrgico, obtuvimos que los pacientes operados antes de los 3 meses de evolución tenían un promedio de 1,1 en grado de infiltración grasa de Goutallier. Y los operados después de los 3 meses de evolución tenían un grado de infiltración grasa de 1,5. Al comparar dolor (EVA) con infiltración grasa obtuvimos que para el grado 0 (EVA 1), grado 1 (EVA 1.54), grado 2 (EVA 0.33) y grado 3 (EVA 1). Al comparar con inicio de Natación y/o Pilates en días postoperatorio con infiltración grasa obtuvimos para el grado 0 (90 días), grado 1 (95 días), grado 2 (70 días) y grado 3 (120 días).

La atrofia muscular del supraespinoso se valora en el corte sagital de RMN en donde obtenemos un valor promedio de 0.69 , es decir un valor cercano a una atrofia grado 1 o ligera. La retracción tendinosa del supraespinoso, obtenemos un valor de 1.37. Es decir, un valor de retracción entre la inserción (más cercano a este) y cabeza humeral. El dolor, utilizando la escala EVA, valorado en la primera consulta (media de 6.1), postoperatorio a los 7 días (media 4.31), a los 30 días (media 2.5) y a los 60 días (media 1.25). Se observa una disminución del dolor con el tratamiento 
quirúrgico. También encontramos que los pacientes operados antes de 3 meses de evolución de la lesión manifestaron un puntaje de dolor al final del tratamiento y rehabilitación de 1,18 ; menor en comparación con los que se operaron posteriores a los 3 meses de evolución de 1,6.

Los pacientes que comenzaron con natación al segundo mes postoperatorio fueron porque mostraron una mejoría en los parámetros movilidad y dolor tras la cirugía. Siendo esto beneficioso para la recuperación y el alta temprana.

Se observó una sola complicación en la serie, en donde se pudo objetivar una re-ruptura del supraespinoso. La misma evoluciono correctamente con tratamiento médico conservador, fisioterapia. Esta complicación represento el $6.25 \%$ de la muestra.

\section{Discusión}

La Omalgia tiene muchas etiologías entre las que se encuentran la lesión del manguito rotador. Un diagnostico estructural definitivo como origen del dolor es inalcanzable, por lo que se aceptan términos como dolor del manguito rotador, esto dado al diseño que no permite la valoración musculo tendinosa individual, debido a la fusión de sus tendones cerca de su inserción. Sin embargo, se han evidenciado lesiones aisladas del tendón del supraespinoso como causa de Omalgia que conlleva a limitación funcional y motivan al paciente a consultar.

En nuestro estudio encontramos que el Dolor disminuyo notablemente durante las valoraciones postquirúrgicas, independiente del grado de infiltración grasa. Los pacientes a quienes se operaron dentro de los primeros 3 meses tuvieron menor dolor a comparación con los que se operaron posterior al tiempo referido.

Estudios demuestran que el tendón del supraespinoso tiene una capacidad limitada de curación si no se repara rápido, correlacionando progresión en retracción y atrofia con el desarrollo de los síntomas. Pacientes que antes eran asintomáticos se volvieron sintomáticos en promedio a los 2 años de evolución de la lesión ${ }^{1,2}$. La edad mayor de 60 años y la degeneración grasa inicial del supraespinoso se correlaciono con la progresión de la lágrima, en un $50 \%$ de los pacientes hacia 2 años ${ }^{1}$.

Muchos factores afectan el patrón del dolor posterior a cirugías artroscópicas reparatorias del manguito rotador. Tanto el acto quirúrgico como también las comorbilidades psiquiátricas, enfermedades inflamatorias, compensaciones laborales y/o económicas; puede estar asociado con dolor postoperatorio severo que puede a su vez afectar la rehabilitación y satisfacción del paciente, lo que influye en los resultados funcionales a largo plazo $^{2}$.

La herramienta EVA para medición del dolor es un instrumento simple, sólido, sensible y reproducible, siendo útil para reevaluar el dolor en el mismo paciente en diferentes ocasiones ${ }^{1}$.

Se han llevado a cabo investigaciones sobre el control temprano del dolor postoperatorio, que a menudo muestran buenos resultados. Sin embargo, la mayoría de la literatura ha evaluado los métodos y resultados del control del dolor postoperatorio temprano solamente, mientras que el grado de dolor postoperatorio y los patrones de cambio durante el período de seguimiento son ampliamente desconocidos ${ }^{8}$.

La reparación del musculo supraespinoso es un tratamiento exitoso en términos de satisfacción del paciente y alivio del dolor, independientemente del método de reparación. Aunque generalmente se piensa que la reparación artroscópica es menos dolorosa que la reparación abierta o Mini - Open, los estudios no concuerdan en este punto ${ }^{9}$.

La reparación artroscópica del manguito rotador es un procedimiento quirúrgico efectivo $\mathrm{y}$ mínimamente invasivo que puede disminuir el dolor y aumentar la función permitiendo a los pacientes mejorar su calidad de vida. Los factores que afectan los resultados después de la reparación del supraespinoso incluyen calidad del tendón, infiltración grasa, tamaño de la lagrima y retracción, cronicidad de la lesión, edad del paciente y otras comorbilidades a tener en cuenta al indicar manejo quirúrgico ${ }^{3}$.

La evaluación de la degeneración grasa mediante RMN esta aceptada y validada, ofrece una estimación de la calidad muscular y nos da una predicción de los posibles resultados clínicos después de la reparación. Existen métodos más sensibles como la espectroscopia MR, que puede proporcionar información adicional y aumentar la calidad de la clasificación de Goutallier, dado que la fiabilidad depende del lector en una estimación cualitativa vista en la RMN, pero este método aún se encuentra en etapas experimentales ${ }^{7}$.

La implementación de un programa de fisioterapia acuática y natación (estilo Crawl o Aquagym) en la recuperación postquirúrgica del paciente, ha evidenciado una ayuda tanto en la rehabilitación como también en los rangos de movilidad y funcionalidad del manguito rotador ${ }^{10}$.

\section{Conclusión}

Los resultados obtenidos en nuestro centro son similares a la literatura científica, la edad es directamente proporcional a la degeneración grasa, sea de origen traumático o a traumática. En nuestra 
serie no hubo diferencia entre los pacientes que tuvieron menor o mayor grado de degeneración y atrofia con respecto a la satisfacción final. Se demostró que entre más aguda la lesión y su pronta reparación, el dolor es inferior al final de la recuperación.

\section{Introduction}

Omalgia has many etiologies, among which are rotator cuff lesions, as a cause alone or accompanied by other comorbidities. The rupture of the supraspinatus muscle is one of the main causes of this, and its injury results not only in pain, but also in functional limitation.

The natural history of rotator cuff tears is not always predictable, on the one hand, many are asymptomatic and respond well to conservative management. On the other hand, there are studies that suggest that some tears that were previously asymptomatic become symptomatic and the manifestation of pain is one of the most used criteria for surgical management ${ }^{1}$.

The pathology of the rotator cuff is very frequent, anatomical studies on corpses found rupture up to $50 \%$ of cases, suggesting that it can be part of the aging process, increasing steadily after the fifth decade of life. Other studies showed normal function even with full thickness rupture ${ }^{1,2}$.

The surgical treatment by arthroscopic route has taken boom in the last years, offering great expectations to the patient on the postsurgical result. However, there are factors that can affect the outcome of the surgery such as tendon quality, retraction size and fat infiltration ${ }^{3}$.

The evaluation of the abnormalities of the rotator cuff muscle after its rupture is an important factor for decision making at the time of treatment. The severity of pre-surgical fat degeneration is especially relevant since it influences the prognosis and postoperative functional recovery. An accurate determination of fat degeneration in the supraspinatus muscle is, therefore, a crucial element to evaluate surgical indications and postoperative prognosis ${ }^{4}$.

Goutallier showed that the longer the symptoms, the greater the fat degeneration of the muscle whose tendon is broken, also showed that the rate of re-rupture was less when there was minimal fat degeneration, and that after the repair this fat degeneration of the Supraspinatus reverted by $21 \%$; On the other hand some studies show that the muscle does not regenerate, supporting the idea of a quick surgery before fat degeneration occurs ${ }^{5}$. The Goutallier classification is highly accepted as a standard 5-grade grading system for muscle fat degeneration, based on sagittal MRI images 5 .
The loss of contractile force of the supraspinatus and consequent weakness is associated with muscular atrophy, and exacerbated by fatty infiltration, both degenerative changes secondary to rupture of the rotator cuff. The measurement of fat infiltration and preoperative muscle atrophy will help us to predict the contractile function of the muscle and its recovery ${ }^{6}$.

\section{Objective}

To determine the degree of pain and postsurgical functionality of the supraspinatus tendon according to the presurgical tendon quality.

\section{Material and method}

Observational type study, case series and retrospective. A search was made in the computer system of clinical records in electronic clinic support (HIS INNOVA $®)$, of all patients with total tear of the supraspinatus muscle who underwent arthroscopic and Mini - Open surgery, from January 2016 to January 2018.

We include patients of all ages, with a traumatic and atraumatic type of rupture, different time in the evolution of the disease, of both sex and different work activity.

We excluded patients with lesions of 2 or more tendons of the rotator cuff, previous surgeries of the evaluated shoulder, and those whose follow-up was less than 4 months due to different causes.

Fat degeneration using the Goutallier Classification from 0 to 4 was evaluated in the preoperative using MRI, using T1 images in axial section. Grade 0 was defined as absence of fatty infiltration, grade 1 as fatty streaks of the supraspinatus, grade 2 as less fat than muscle, grade 3 as equal amounts of fat and muscle, and grade 4 as more fat than muscle ${ }^{5}$. Muscle atrophy of the supraspinatus was also assessed with sagittal section at the level of the medial edge of the scapular spine just above the spinoglenoid notch, classifying from 1 to 3 according to the percentage of muscular occupation in supraspinosa fossa as follows: grade 1 normal or light atrophy (1 - 0.6), moderate grade 2 atrophy $(0.6-0.4)$ and severe grade 3 atrophy $(<0.4)$. And tendinous retraction of the supraspinatus according to anatomical references in insertion, humeral head or at the level of the glenoid in coronal section.

All assessments were made by an orthopedist and a resident of the same specialty.

The surgical technique is performed by arthroscopic and Mini - Open anterolateral approach, placing 2 linear sutures and harpoons with double suture to approximate the tendon to 
Footprint area, wound closure by planes and placement of a Vietnam type sling.

Postoperative control was performed at $7,15,30$, 60 and 90 days, evaluating postoperative pain, range of flexion and abduction, both active and passive.

The patients started at 7 days swings and passive shoulder flexion, at 15 days physiotherapy passive motion indicated, at 30 days active and assisted mobility, between 45 to 60 days swimming (crawl or Aquagym style) and / or Pilates according to pain evolution and range of mobility.

Pain, as a primary reason for consultation, was evaluated by means of the EVA scale, with a numerical value of 0 to 10 where 0 is absence of pain and 10 is the worst unimaginable pain.

The range of movement was evaluated in degrees, both active and passive, always by the same examiner, as well as the degree of pain.

\section{Results}

We analyzed 16 patients, 7 men (44\%) and 9 women $(56 \%)$, with an age range between 45 and 70 years (mean 58.6 years), assessed by means of MRI, where we calculated fat degeneration with the Goutallier classification. 0 to 4 , obtaining an average of 1.2 , that is, a value of minimum fat infiltration. Grouping in degree of fat infiltration by age in years, we obtained for grade 0 (average 51 ), grade 1 (average 59.4), grade 2 (average 60.3) and grade 3 (average of 62); we did not have patients with grade 4 . Compared with the time of evolution from diagnosis to surgical management, we obtained that patients operated before 3 months of evolution had an average of 1.1 in degree of fatty infiltration of Goutallier. And those operated after 3 months of evolution had a degree of fat infiltration of 1.5. When comparing pain (EVA) with fatty infiltration we obtained for grade 0 (EVA 1), grade 1 (EVA 1.54), grade 2 (EVA 0.33) and grade 3 (EVA 1). When compared with the start of swimming and / or Pilates on postoperative days with fatty infiltration we obtained for grade 0 (90 days), grade 1 (95 days), grade 2 (70 days) and grade 3 (120 days).

Muscular atrophy of the supraspinatus is evaluated in the sagittal section of the MRI, where we obtain an average value of 0.69 , that is, a value close to a grade 1 atrophy or slight. The tendinous retraction of the supraspinatus, we obtain a value of 1.37 . That is, a retraction value between the insertion (closest to this) and the humeral head.

Pain, using the EVA scale, assessed at the first consultation (average of 6.1), postoperative at 7 days (mean 4.31), at 30 days (mean 2.5) and at 60 days (mean 1.25). There is a decrease in pain with surgical treatment. We also found that patients operated before 3 months of evolution of the lesion showed a pain score at the end of the treatment and rehabilitation of 1.18; lower compared to those who underwent surgery after 3 months of evolution of 1.6.

The patients who started swimming the second postoperative month were because they showed an improvement in mobility and pain parameters after surgery. This being beneficial for recovery and early discharge.

A single complication was observed in the series, where it was possible to objectify a re-rupture of the supraspinatus. It evolved correctly with conservative medical treatment and physiotherapy. This complication represented $6.25 \%$ of the sample.

\section{Discussion}

Omalgia has many etiologies among which are the rotator cuff injury. A definitive structural diagnosis as the origin of pain is unattainable, so terms such as rotator cuff pain are accepted, this given to the design that does not allow individual tendon muscle assessment, due to the fusion of their tendons near their insertion. However, isolated lesions of the supraspinatus tendon have been shown as a cause of Omalgia that leads to functional limitation and motivates the patient to consult.

In our study, we found that the odor decreased markedly during postoperative evaluations, regardless of the degree of fatty infiltration. The patients who underwent surgery within the first 3 months had less pain compared to those who operated after the aforementioned time.

Studies show that the supraspinatus tendon has a limited healing capacity if it is not repaired quickly, correlating progression in retraction and atrophy with the development of symptoms. Patients who were previously asymptomatic became symptomatic on average after 2 years of evolution of the lesion ${ }^{1,2}$.

Age over 60 years and the initial fat degeneration of the supraspinatus correlated with the progression of the tear, in $50 \%$ of the patients around 2 years ${ }^{1}$.

Many factors affect the pattern of pain after arthroscopic repair of the rotator cuff. Both the surgical act as well as psychiatric comorbidities, inflammatory diseases, work and / or economic compensations; it can be associated with severe postoperative pain that can in turn affect rehabilitation and patient satisfaction, which influences long-term functional outcomes ${ }^{2}$.

The EVA tool for pain measurement is a simple, solid, sensitive and reproducible instrument, being 
useful to reevaluate pain in the same patient on different occasions ${ }^{1}$.

Research has been carried out on the early control of postoperative pain, which often shows good results. However, most of the literature has evaluated the methods and results of early postoperative pain control only, while the degree of postoperative pain and the patterns of change during the follow-up period are largely unknown ${ }^{8}$. Repair of the supraspinatus muscle is a successful treatment in terms of patient satisfaction and pain relief, regardless of the method of repair. Although it is generally thought that arthroscopic repair is less painful than open or Mini-Open repair, the studies do not agree on this point ${ }^{9}$.

Arthroscopic rotator cuff repair is an effective and minimally invasive surgical procedure that can decrease pain and increase function allowing patients to improve their quality of life. The factors that affect the results after supraspinatus repair include tendon quality, fatty infiltration, tear size and retraction, chronicity of the lesion, age of the patient and other comorbidities to be taken into account when indicating surgical management ${ }^{3}$.

The evaluation of fat degeneration by means of NMR is accepted and validated, offers an estimation of muscular quality and gives us a prediction of the possible clinical results after the repair. There are more sensitive methods such as MR spectroscopy, which can provide additional information and increase the quality of Goutallier's classification, since reliability depends on the reader in a qualitative estimation seen in MRI, but this method is still in experimental stages ${ }^{7}$.

The implementation of a program of aquatic physiotherapy and swimming (Crawl or Aquagym style) in the postoperative recovery of the patient has evidenced a help both in the rehabilitation as well as in the ranges of mobility and functionality of the rotator $\operatorname{cuff}^{10}$.

\section{Conclusion}

The results obtained in our center are similar to the scientific literature, age is directly proportional to fat degeneration, whether traumatic or atraumatic. In our series, there was no difference between the patients who had a lower or higher degree of degeneration and atrophy with respect to final satisfaction. It was shown that the more acute the injury and its prompt repair, the pain is inferior to the end of recovery.

\section{Bibliografía}

1. Robert Z. Tashjian, Epidemiology, Natural History, and Indications for Treatment of
Rotator Cuff Tears. Clin Sports Med 2012;589-604.

2. Yamaguchi K, Tetro AM, Blam $\mathrm{O}$, et al. Natural history of asymptomatic rotator cuff tears: a longitudinal analysis of asymptomatic tears detected sonographically. J Shoulder Elbow Surg 2001;10:199-203.

3. Novoa Alejandro, Lawrence Gulotta. Expectations following rotator cuff surgery. Curr Rev Musculoskelet Med. 2018 Mar;11(1):162-166.

4. Horiuchi S, Nozaki T, Tasaki A. Reliability of MR Quantification of Rotator Cuff Muscle Fatty Degeneration Using a 2- point Dixon Technique in Comparison with the Goutallier Classification: Validation Study by Multiple Readers. Acad Radiol 2017;03-026.

5. Fabian Gilbert, Dirk Böhm, Lars Eden, Jonas Schmalzl, Rainer H. Meffert, Herbert Köstler, Andreas M. Weng and Dirk Ziegler. Comparing the MRI-based Goutallier Classification to an experimental quantitative MR spectroscopic fat measurement of the supraspinatus muscle. Gilbert et al. BMC Musculoskeletal Disorders 2016; 17:355

6. Deniz G, Kose O, Tugay A, Guler F, Turan A. Fatty degeneration and atrophy of the rotator cuff muscles after arthroscopic repair: Does it improve, halt or deteriorate? Arch Orthop Trauma Surg. 2014; 134:985-90.

7. Fabian Gilbert, Dirk Böhm, Lars Eden, Jonas Schmalzl, Rainer H. Meffert, Herbert Köstler, Andreas M. Weng and Dirk Ziegler. Comparing the MRI-based Goutallier Classification to an experimental quantitative MR spectroscopic fat measurement of the supraspinatus muscle. Gilbert et al. BMC Musculoskeletal Disorders 2016;17:355

8. Jeremy Lewis. Rotator cuff related shoulder pain: Assessment, management and uncertainties. Manual Therapy 23 2016;57-68

9. Geral Williams Jr, Matthew J. Kraeutler. No Difference in Postoperative Pain After Arthroscopic versus Open Rotator Cuff Repair.Clin Orthop Relat Res. 2014 Sep; 472(9):2759-2765.

10. Brady B, Redfern J, MacDougal G. The addition of aquatic of therapy to rehabilitation following surgical rotator cuff repair: a feasibility study. Physiother Res Int. 2008 Sep; 13(3):153-61. 
Herrera Burgos Daniel, Balla Mauricio, Ferreyra Cristian A, Jalil Andrés M. Correlación entre calidad del tendón del supraespinoso con el dolor y movilidad postquirúrgica.

\section{Palabras Clave}

RUPTURA SUPRAESPINOSO, REPARACIÓN

ARTROSCÓPICA, DOLOR

POSTQUIRÚRGICO, DEGENERACIÓN

GRASA, GOUTALLIER.

\section{Keywords}

SUPRASPINOUS RUPTURE,

ARTHROSCOPIC REPAIR, POSTOPERATIVE

PAIN, FATTY DEGENERATION,

GOUTALLIER.

\section{(c) (1)(8)(0)

